\title{
Interpretation of “Dear Me Beauty" Product Rebranding: Twitter Users Analysis
}

\author{
Lambok Hermanto Sihombing ${ }^{*}$, Dinda Putri Yanab ${ }^{2}$, Dwi Aulia Syifayantie ${ }^{3}$ \\ Department of Communication, President University \\ 1lambok.president@gmail.com \\ *Penulis koresponden
}

\begin{abstract}
The large number of cosmetic industries make every company need to survive and compete among others. Marketers have to find out the best strategy in order to survive and control their target market. One of the best strategies is rebrandring. This strategy has been done by many companies and one of them comes from cosmetic industry which is "Dear Me Beauty". The aims of this study is to discuss the way "Dear Me Beauty" rebranding their brand by launching new products after they have a brand crisis. The data of this research was obtained from the comment of Twitter users. This study used the encoding decoding theory from Stuart Hall. The findings of this study was the response from Twitter users was positive, implying that "Dear Me Beauty's" rebranding was successful. The researchers discovered that the messages from "Dear Me Beauty" conveyed through their newest product could be well interpreted and accepted by the public.
\end{abstract}

Keywords: Brand, crisis, marketers, rebranding

\section{Introduction}

Branding is a critical means through which firms align their strategy, culture, and identity, too (Rao, Agarwal, and Dahlhoff, 2004). According to Hampf, A., \& LindbergRepo (2011), they stated that branding, as any other concept, has evolved over time: from the days when sheep of one herd started to be branded to distinguish them from another herd to the current era when everything, from water and flowers to clothes and food, is branded. A brand is essentially a seller's promise to deliver a specific set of features, benefits, and services consistently to the customers (Kotler and Armstrong, 2010). It helps enterprises to communicate desirable images about the quality, features, and uniqueness product offerings (Keller, 2003). In addition, brands are promises that consumers believe in (Chiaravalle, B. \& Schenck, 2014). They also stated that building brands takes focus, passion, persistence, and diligence. Plus brand building requires effort and money. The payoff, and it's a big one, is that strong brands build business and equity for their owners. The following sections shed light on what brands do and why they're such a big deal. Brands create consumer trust and emotional attachments. As a result, they foster relationships between consumers and products that withstand pricing wars, transcend offers from new competitors, and even overcome rare lapses in product or service excellence. According to Clark (2004). He stated that a brand is a representation of a company, person, or group that connects and communicates with consumers to remain relevant. One of the fundamentals for this is creating a brand with high credibility and trust (Reichheld \& Schefter, 2000). By emphasizing the key elements of branding, such as personality, differentiation, and mutual benefit, companies can ensure that their brands are able to gain consumer trust, confidence, and loyalty-resulting in wide recognition and longevity for the strongest brands (Echevarria, R. M., 2017).

Brands grow and adapt with trends and must constantly be conscientious of how they are perceived in the minds of the consumer. However, it is important that a brand remains true to its original purpose and does not lose its identity as it adjusts based on consumer needs (Clark, 2004). It is also in accordance with Miletsky \& Smith (2009) and Wood (2000). They stated that brand refers to a name, term, design, symbol, or other feature that differentiates one entity from another, and builds both reputation and future 
expectations of benefit. Wood (2000) also stated that "Brands operate in a market where differentiation is crucially important" because it affects how a brand positions itself both in the minds of the consumer and its competitors.

Brand communication, the process of examining the relevance of such meanings and symbolism and adjusting these to the mission and vision of the enterprise and to the market realities, has become a key marketing activity of most business organisations (Eagle and Kitchen, 2000). A strong brand should have a rich, clear brand identity - a set of associations the brand strategist seeks to create or maintain. In contrast to brand image, brand identity represents what the organization wants the brand to stand for (Aaker and Joachimsthaler, 2000). A brand should be able to communicate that it is better than the other brands on parameters that customers evaluate; equally important, it should match with the customers' personality (Ailawadi and Keller, 2004). Hereby, in running a business, a brand has an important role. In fact, a company can spend a lot of money to make their brand known by the public, even to be known with a good image. Even though they have already done many ways to make their brand known with a positive image, it doesn't mean that a company can't experience a brand crisis. According to Salvador \& Ikeda (2017), a crisis is a sudden and unexpected event that can threaten organizational goals, can cause financial losses, and damage the company's reputation. Therefore, a crisis can happen anytime, anywhere, and to anyone. Crisis can also affect companies, as well as products, services, and brand image. In addition, Dutta and Pullig (2011) conceptualized brand crisis as unexpected events that threaten a brand's perceived ability to deliver expected benefits. Brand crisis are among a firm's worst nightmares, causing both short- and longterm negative effects such asimmediate loss in own-brand sales, reduced effectiveness of marketing instruments, consumer trust (Van Heerde et al., 2007; Xie and Peng, 2009)

In Indonesia, there are several brand crisis cases that ever happened. One of them was the local makeup brand, "Dear Me Beauty", also faced a similar situation. Their brand went viral overnight. However, being viral doesn't only have a positive impact but it can also lead to a negative impact for a person, brand, even company. This incident started on Friday July 24th, 2020, and at that time "Dear Me Beauty" posted a promotion video of their newest product called Perfect Conceal Serum Skin Corrector on their official TikTok and Instagram accounts. In this product, there are six color choices available that are intended for bright skin, medium, and medium-plus skin. Then, one of TikTok users asked in the comment section about why "Dear Me Beauty" didn't provide a darker shade. However, the social media users think that the admin of "Dear Me Beauty" responded with an incorrect answer. They didn't respond with appropriate communication ethics. The response from "Dear Me Beauty"'s admin was considered arrogant, which then caused criticism and anger from the social media users, especially on Twitter.

Based on Twitter users' opinion, the admin should be wise in choosing sentences to convey on social media because the way the admin communicates and responds to the customers, it represents their brand image. This case created a bad image for "Dear Me Beauty" as their brand is considered not supporting the diversity of Indonesian people.

Not only criticized by the general public, the crisis that befell "Dear Me Beauty" also received a response from a beauty influencer who usually collaborates with make-up brands, especially local brands. The beauty influencer called Liv tweeted on her official Twitter account @livjunkie saying that she would not support a brand that only has a good attitude in front of her but rude to their customers. This triggered the case to become increasingly viral and reaped a lot of negative comments on Twitter.

As a result of this crisis, the brand of "Dear Me Beauty", which was previously known to have a good image, turned into bad just overnight. Not only bad for the brand image of "Dear Me Beauty" itself, this crisis has also caused calls to stop buying "Dear Me Beauty" products, even a lot of Twitter users tweeted "Cancelled "Dear Me Beauty"' on their Twitter accounts. Hence, "Dear Me Beauty" tried to turn the situation to be as conducive as before. They edited the comment that was previously considered rude to become 
friendlier, but of course this kind of act would not have much effect because people have already assessed the image of "Dear Me Beauty" as a bad brand.

Branding is important for a brand to have, because it can be a hallmark of a brand. There needs to be an effort in branding to form an identity that can represent a brand called a brand identity. A good brand enhances both brand loyalty and brand equity, which can seriously damage the company itself if it is affected (Aaker, 2010). Brands are a big business today because they make selling easier in person and online. People prefer to buy from companies they feel they know and can trust, and brands put forth that assurance (Chiaravalle, B. \& Schenck, 2014). Branding could be done by promoting and advertising on social media as social media can be a twoway communication between a brand and its customers, and that is what "Dear Me Beauty" had done until now.

Due to a bad image "Dear Me Beauty" had, it made them think to clean their bag image. They did it by rebranding. Tevi (2013) explained that rebranding is a new name, designation, sketch, or composition of a company or brand after they decided to change it for developing a new position in the mind of customers, stakeholder, and also competitor. In line with this, Goi and Goi (2011) agree that in doing a rebranding, the company may do an explicit changes such as physical appearance or expression of the brand, or an inexplicit changes such as values, portray, or feelings in the elements of the brand.

According to Stuart Hall quoted by Hallgren (2018), encoding-decoding is a part of the language process which gives a sign in the discourse of the ideological meaning and value. Simply, encoding can be interpreted as the process of creating a message, while decoding is the process of interpreting the message. Stuart Hall quoted by Hallgreen (2018) also stated that the codes of encodingdecoding may not be interpreted in the same way by the audience. However, the audience interpretation is really important because it could determine the meaning of a text. If the audience doesn't understand the intended meaning, there will be no meaningful discourse or effective communication. Therefore, the reason for selecting this concept was because it was suitable to become the basis of thinking in identifying the meaning of Twitter user's comments related to the rebranding of "Dear $\mathrm{Me}$ Beauty".

According to the research of Merille quoted from Stuart (2017), rebranding can succeed when the organization considers the brand vision, brand orientation, and brand strategy. In brand vision, the corporate needs to decide their new positioning. Brand orientation is when the corporate receives internal endorsement from key stakeholders. Brand strategy is when the corporate implements the way to rebrand. Meanwhile, Muzellec and Lambkin stated from Goi and Goi (2011), there are three important things in the rebranding model, such as rebranding factors, rebranding goals, and rebranding process. The rebranding factors and goals are the two of the rebranding goals are the drawing in creating the new personality and identity. The rebranding process aims to point out the entanglement of the internal employees and the external stakeholder to create the cultural image and the image of the company. To understand the basic principle of rebranding could be depicted as the model in Fig. 1.

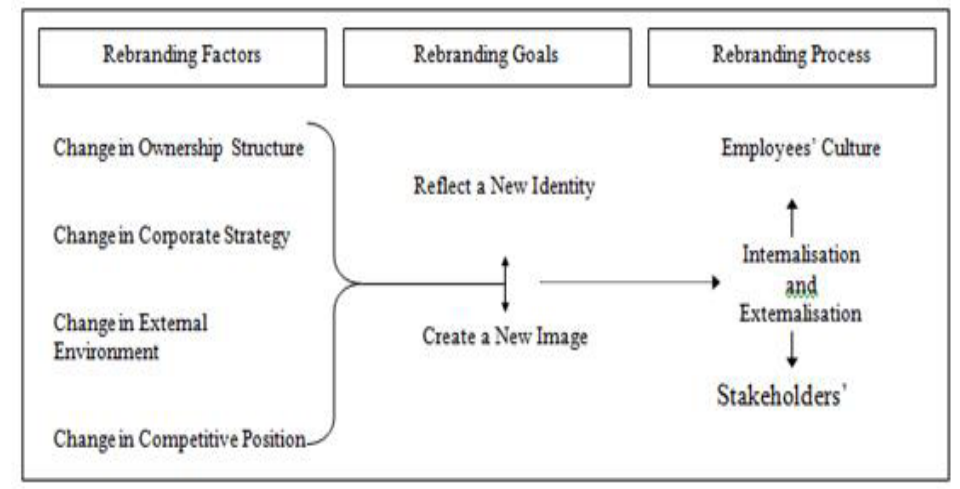

Figure 1. Rebranding Process Model 
In order to achieve good branding, it takes several actions that need to be done by a brand. According to Blakeman (2018), those actions are:

1. Defining a brand: To start the actions, the brand needs to define their brand. Here, a brand needs to show their personality, image, and message. The personality can include the physical features of the product, whereas image can include what a brand wants their consumer to see their brand as.

2. Positioning a brand: Positioning a brand is important because there are a variety of products and brands in the market. Positioning can make a brand look unique and makes it easier for the target market to recognize the specialty of one brand towards other brands.

3. Developing brand identity: Brand identity includes the elements that will be the hallmark of a brand. For example: logo, colors, and tagline.

By doing those actions, it will determine how the consumer thinks about the product or service of a brand and how it stands out from the competition. And product's reputation in the marketplace.

However, when a brand is experiencing a crisis, the company will provide an answer so that the crisis does not have a wider impact and the image of the brand does not fall too much. Denial of responsibility to acceptance of responsibility, as well as legal obligations (super effort) and efforts to compensate society, are possible responses (Salvador, A. B., \& Ikeda A. A., 2016). Crisis caused by communication between the company and customers in the media tends to spread more easily and, if not immediately addressed, exacerbates the crisis. Because when they see an error that has occurred, people who see it tend to spread and discuss it. It will therefore cause a crisis for the brand. There are 5 stages of crisis, there are:

1. Detection: Noting some warning signs or prodromal stage

2. Prevention: Making two-way communications and build relationship with key public

3. Containment: Limiting the duration of a crisis or preventing it from spreading to other parts of the organization
4. Recovery: Getting the company back to normal operations

5. Learning: Analyzing a crisis to see what was lost, what was gained, and how the organization performed during the crisis (Fearn-Banks, 2011).

On the previous reseach "Does Trust and Hedonic Motivation Enhance Purchase Intention" written by Benedict Valentine Arulanandam from Sunway University, Kuala Lumpur, Malaysia and Helma Malini and Fiola Oktaningtias from Tanjungpura University, Pontianak, Indonesia, they stated that Instagram gave easy access for us to look for the products we want to buy through the advertisements and features Instagram have. In addition, Instagram will give the hedonic motivation to the consumer because they can see various lipstick products that have been provide by "Dear Me Beauty" brand and through Instagram stories features that are mostly done on Instagram. From this previous research, the reseachers viewed that the writers focused on defining the the influence of hedonic motivation that Instagram offers to enhance consumer purchase intention beauty lipstick products. They used "Dear Me Beauty" brand but they didn't use it as the main object. Meanwhile, in this study, the researchers analyzed how people viewed a brand reputation of "Dear Me Beauty" presented on social media, Twitter. The resesearcher used "Dear Me Beauty" brand as the main object of the study.

\section{Methods}

According to Becker, H., Namaan, Mor \&Gravano, L. (2011), twitter is a popular social media site that allows users to post short textual messages, or tweets, which are up to 140 characters long. Twitter users can use a hashtag annotation format (e.g., \#sb45) to indicate what their messages are about (e.g., "watching Superbowl 45 \#sb45"). In addition, Twitter allows several ways for users to converse and interact by referencing each other in messages using the @ symbol. Twitter currently employs a proprietary algorithm to display trending topics, consisting of terms and phrases that exhibit "trending" behavior.

In this study, the researchers analyzed the tweets and comments towards the rebranding of "Dear Me Beauty". First element was selecting the Twitter accounts 
with most likes, retweets, and comments about the rebranding of "Dear Me Beauty" that went viral in that time. Second, the researchers analyzed the wording on the tweet from the Twitter users @bittentaco and @zsaazsaazsu. Next, the comments and quote tweet from the other twitter users as the audience that reacted to the tweet made by @bittentaco and @zsaazsaazsu related to the rebranding of "Dear Me Beauty". The last step was applying the concept of encodingdecoding.

\section{Result and Discussion}

"Dear Me Beauty" lost their trust from the customers and received hatred from the public. Some comments were showing that they canceled to purchase "Dear Me Beauty" products, replaced their product with another brand, and one of the most important disappointments for being impolite to the customer that made people lose their respect for "Dear Me Beauty". This phenomenon made Dear Me Product fail in handling their good brand image in social media.

The first step that "Dear Me Beauty" decided to do was making a clarification and apologies (Fig. 2) to the public who were offended with the way "Dear Me Beauty" threatened the customer on TikTok through their Twitter account. This step was conducted to gain back the trust from the public, creating the space for the public to engage, also to produce their message to the customer.
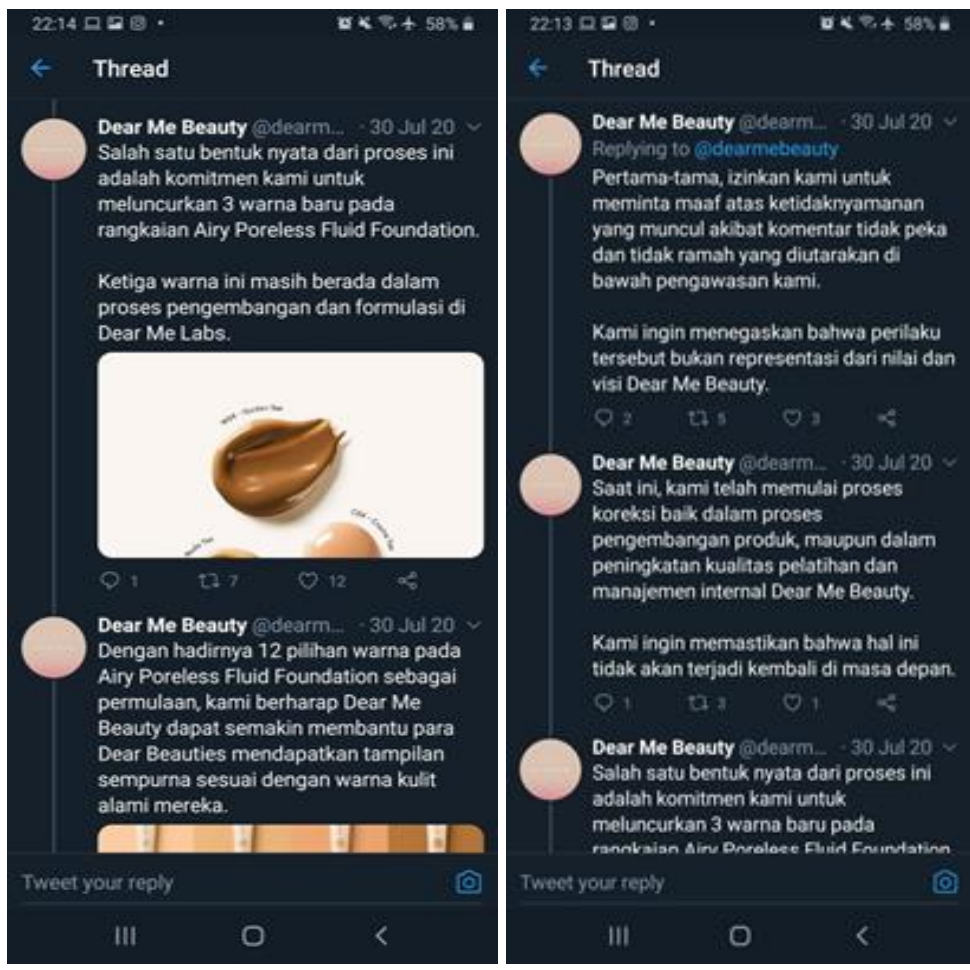

Figure 2. Screenshot of Apologize from "Dear Me Beauty" and Progress of Issue Source:https://twitter.com/dearmebeauty/status/1288820945860218880?s=19

The activity of interaction between the brand and the public was shown by the tweets from the Twitter users as a feedback and also reaction to the launch of the "Dear Me Beauty" product after their failure. In this analysis, the researchers had chosen two tweets that had the most likes, comments, retweets, and quotes tweet from the user @zsaazsazsu on 01 February 2021 with 48.500 likes, 8.602 retweets, 1.130 quote tweets, 417 comments. Also a tweet from user @bittentaco on 01 February 2021 with
32.800 likes, 9.564 retweets, 707 quote tweets, and 139 comments. Tweets from both users explained and took the role in the meaning-making message towards the rebranding of "Dear Me Beauty" by launching a new product. It also attracted a larger public to engage and react.

Following the previous described cases, "Dear Me Beauty" underwent a rebranding. This was done to reestablish people's trust in "Dear Me Beauty", and "Dear Me Beauty" believes they need to rebrand because public 
trust in their brand was dwindling, and they must act quickly to avoid further damage to the brand. Rebranding of "Dear Me Beauty" was through several stages, one of which was the release of a new product. "Dear Me Beauty" released a foundation product with various shades that can be applied to various skin tones on January 28, 2021. "Dear Me Beauty" Airy Poreless Fluid Foundation is the name of the product. "Dear Me Beauty" went through several stages of rebranding before releasing this product. According to Alahuhta quoted by Tevi (2013), there are seven phases in the process of rebranding, which are: trigger, analyze, make decision, plan, prepare, launch, evaluate, and continue the stage.

"Dear Me Beauty" rebranded based on these eight processes because there was a trigger. "Dear Me Beauty" analyzed what happened to the brand and company after the case before making a decision. "Dear $\mathrm{Me}$ Beauty" made a decision after determining the source of the problem and successfully analyzing it. On July 30, 2020, "Dear Me Beauty" issued a written apology on Twitter, which elicited a variety of responses from the public. Following that, "Dear Me Beauty" devised a strategy to reestablish the public's trust in the company. Because they were accused of being a racist brand against skin color at the time, they planned and prepared to create a product that was suitable for all skin tones. "Dear Me Beauty" is preparing to launch its newest product on January 25, 2021, announcing that there would be 15 shades to choose from that were suitable for Indonesian facial skin. "Dear Me Beauty"'s product was released on January 28, 2021. "Dear Me Beauty" received a variety of public reactions after the product was released.

The encoding process occurred in this case through the launch of "Dear Me Beauty"'s Airy Poreless Fluid Foundation product, because this product gave the impression that they supported the diversity of skin colors in Indonesia. There was also a decoding process when analyzing the comment from user twitter based on the launch of "Dear Me Beauty"'s Airy Poreless Fluid Foundation product. According to Stuart Hall quoted by Hallgren (2018), "The encoding/decoding practices are part of the language processes that give signs in a discourse their meaning and ideological value" (Hallgren, 2018). Briefly, encoding could be interpreted as the process of creating a message, whereas decoding is the process of interpreting the message.

"Dear Me Beauty" was sending a message by releasing the product that they are not racist against skin color, as was the case in the previous case that happened to them. As a result, they introduced a new product with 15 shades that could match a variety of skin tones and established themselves as the local brand with the most foundation shades. "Dear Me Beauty" rebranded successfully by implementing the seven rebranding processes described earlier. They also implemented an encoding process so that messages could reach the public and receive various types of responses related to their rebranding. Here are some data the researchers found on this study.

The first data was taken from one of the Twitter users, @zsaazsazsu. She tweeted her opinion regarding the rebranding of "Dear Me Beauty" on February 1st 2021. If we analyzed from the contents of her tweet, it could be seen that she uploaded a screenshot from a news portal regarding the newest product of "Dear Me Beauty" which was considered to support the diversity of skin colors. She also added a sentence on her tweet that gave a message that she was proud of "Dear Me Beauty"'s team (Fig 3).

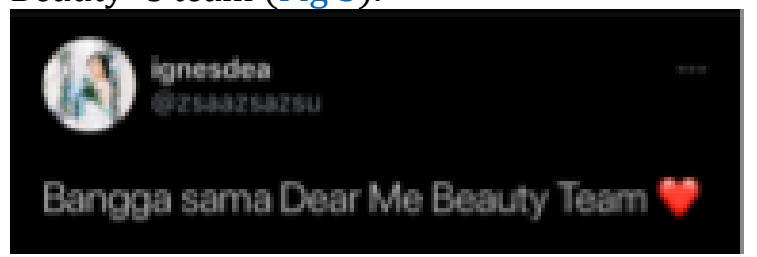

Figure 3. Twitter user opinion towards rebranding of "Dear Me Beauty" from

@zsaazsazsu

Source:

https://twitter.com/zsaazsazsu/status/135 $6175474297171968 ? \mathrm{~s}=21$

Through this first tweet, it could be seen that the twitter user, @zsaazsazsu, interpreted the message delivered by "Dear Me Beauty" well addressing a positive response towards the rebranding of "Dear Me Beauty". The Twitter user even added a screenshot from the news portal to give a clear picture towards the context of her tweet. The analysis of the first tweet can also be done through the Twitter elements, namely like and retweet. Till this day 
$(23 / 03 / 2021)$, this tweet has managed to get 8.601 retweets, 1.130 quote tweets, and 48.500 likes. This actively demonstrates that more than 40 thousand people agreed on the opinions expressed by @zsaazsazsu through her tweets. It could be concluded that the rebranding done by "Dear Me Beauty" was responded positively by @zsaazsazsu and the response was approved by more than 40 thousand people.

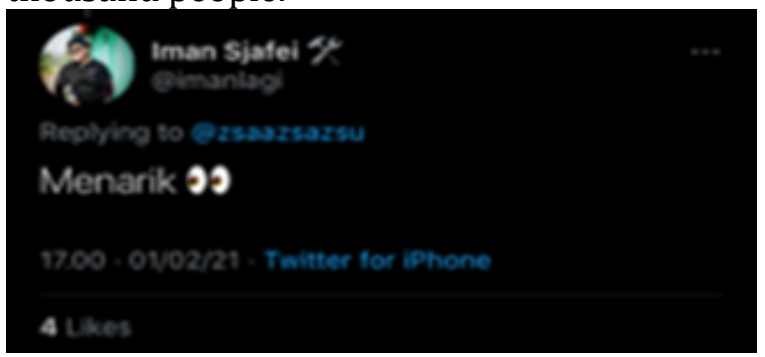

Figure 4. Twitter user opinion towards rebranding of "Dear Me Beauty" from @imanlagi

Source:

https://twitter.com/imanlagi/status/13561 $80639716761600 ? \mathrm{~s}=21$

Through the previous tweet, on February 1st 2021, another comment appeared in the form of reply in the comment column of @zsaazsazsu's tweet. What's interesting was, this comment was given by a Twitter celebrity, namely @imanlagi. Through his tweet, it can be interpreted that he felt that this new product of "Dear Me Beauty" that supported diversity of skin tones was considered interesting (Fig 4.), where interesting here interpreted positively. There were 4 likes in the reply, which actively demonstrated that 4 other Twitter users agreed with Iman's opinion. Therefore, from this second tweet, it can be concluded that the response of Twitter users are still positive. This result is in accordance with the theory of encoding-decoding from Stuart Hall quoted by Shaw (2017) that stated, one of the way for the audience to decode a given message is through a dominant or preferred reading, where the message is translated with the same meaning as intended and when it was encoded.

The third data was also taken from the reply on @zsaazsazsu's tweet. This reply was tweeted by Twitter user with username @L_Genes on February 1st 2021 (Fig. 5).Through his reply, it could be interpreted that he saw that "Dear Me Beauty" is a brand that is serious in giving happiness to its customers, and that's considered cool. This shows that this Twitter user interprets the message from "Dear Me Beauty" well so that the communication flow runs effectively. This is in accordance with the statement from Hallgren (2018) that said, a meaningful discourse or effective communication that can happen if the audience apprehends the intended meaning. If it's also seen from the analysis of Twitter elements, this tweet received 3 retweets and 872 likes. Therefore, it can be interpreted that more than 800 people on Twitter agree with the opinion stated by @L_Genes. Through this tweet, it can be concluded that the public opinion towards the rebranding of "Dear Me Beauty" is still seen positively.

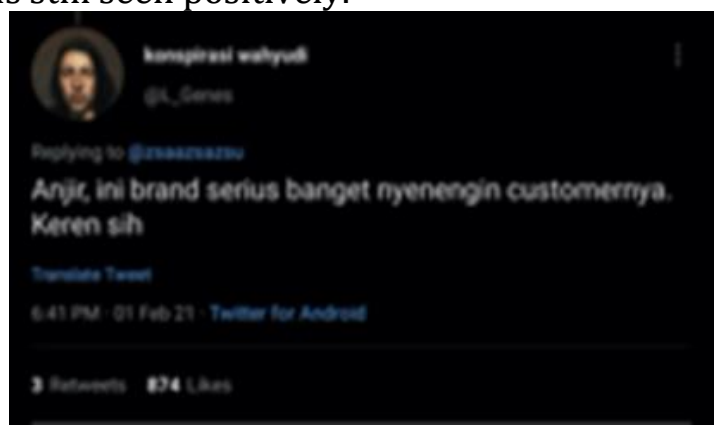

Figure 5. Twitter user opinion towards rebranding of "Dear Me Beauty" from

$$
\text { @l_gene }
$$

Source:

https://twitter.com/l_genes/status/135620 $5935618785292 ? \mathrm{~s}=21$

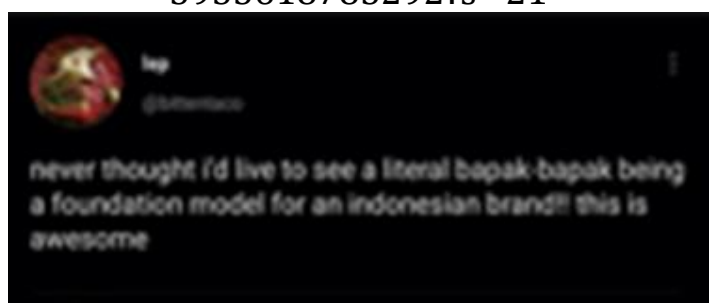

Figure 6. Twitter user opinion towards rebranding of "Dear Me Beauty" from @bittentaco

Source:

https://twitter.com/bittentaco/status/1356 $241601807282179 ? \mathrm{~s}=21$

The fourth data was obtained from one of the Twitter users, @bittentaco (Fig. 6). Through the tweet that was posted on February 1st 2021, the user's surprised that a local brand hired a man to become the model. This tweet can be interpreted positively because at the end of the sentence, the user's also stated that it was awesome. Besides, this tweet can also be interpreted that the user feels that "Dear Me Beauty"'s brand is unique 
because it did something unusual with the concept of the newest product.

From this analysis, it could be seen that the code conveyed by "Dear Me Beauty" could be captured well. This tweet received 9.564 retweets, 707 quote tweets, and 32.800 likes, which as same as the previous tweets, it could be interpreted that the people who liked the tweet agreed to the opinion that stated by @bittentaco. Through this fourth data, it can be concluded the Twitter users opinion is still in a positive way.

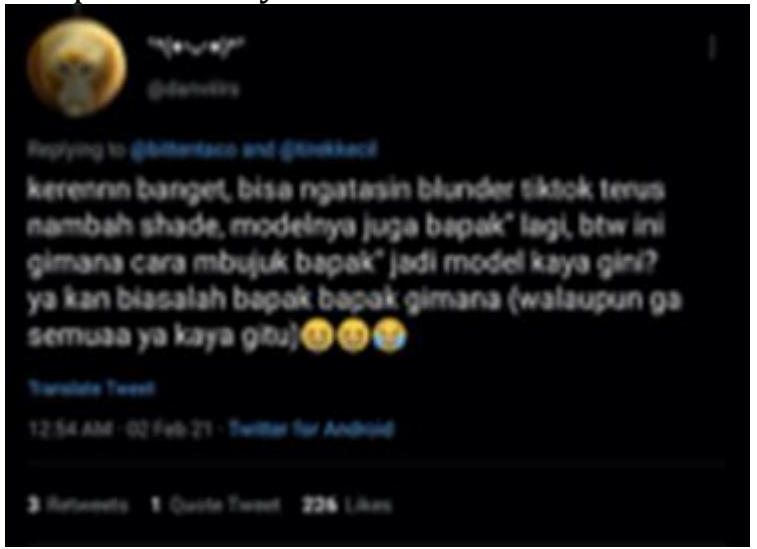

Figure 7. Twitter user opinion towards rebranding of "Dear Me Beauty" from

@danviilrs

Source:

https://twitter.com/danviilrs/status/13563 $00007184367616 ? s=21$

The fifth data was taken from another Twitter user with username @danviilrs (Fig. 7). In the tweet, this user appears to be replying to the opinion that was tweeted by @bittentaco. If seen from the sentence conveyed by this user through the tweet on February 2nd 2021, it can be seen that this user mentioned the brand crisis case that was experienced by "Dear Me Beauty", which was also the beginning of the rebranding of "Dear Me Beauty". This tweet could be interpreted that the user thinks this rebranding is considered cool because it can overcome the blunders that happened on TikTok previously. Therefore, it could be seen that the responses given by one user to another were different even though it was all still in a positive context. Till this day (23/03/2021), this reply had garnered 3 retweets, 1 quote tweet, and 226 likes who approved the opinion in this tweet.

The last tweet was an opinion expressed by user @itnasssn (Fig 8) on February 2nd 2021, where this tweet is also a reply to @bittentaco's tweet (Fig. 6). This tweet had a lot in common with the previous tweet, which they both mentioned about the brand crisis that hit "Dear Me Beauty" previously. This tweet can be interpreted that the user thinks that "Dear Me Beauty" is able to learn from their previous mistake. This user considers that the campaign that conducted by "Dear Me Beauty" was classified as inclusive.

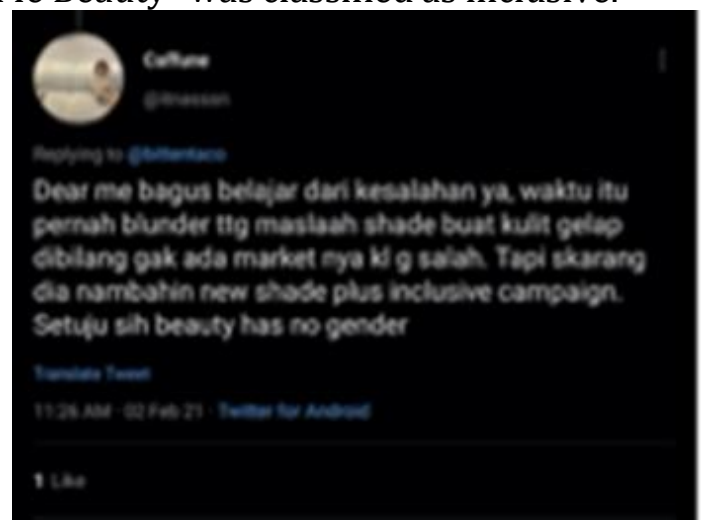

Figure 8. Twitter User Opinion Towards Rebranding of "Dear Me Beauty" From

@itnasssn

Source:

https://twitter.com/itnasssn/status/13564 $59061814861825 ? \mathrm{~s}=21$

\section{Conclusion}

Rebranding is one of effective ways to change people's bad point of view towards a brand. We can see that public has a positive reaction towards the rebranding of "Dear Me Beauty". In other words, we can say that "Dear Me Beauty" successfully overcame the brand crisis that happened to their brand. From the six points of posts that have been analyzed by using encoding and decoding theory, the way the public explained their opinion through Twitter about the rebranding of "Dear Me Beauty" reflected that the public as their customer and general Twitter users supported the steps that the company has done

\section{Refferences}

Aaker, D. (2010). Building strong brands. 1st ed. London [etc.]: Pocket.

Aaker, D. and Joachimsthaler, E. (2000). Brand Leadership. The Free Press, New York, NY.

Ailawadi, K. L. and Keller,K. L. (2004). Understanding retail branding: Conceptual insights and research priorities. Journal of Retailing, 80(4), 331-342. 
Blakeman, R. (2018). Integrated Marketing Communication: Creative Strategy from Idea to Implementation. Rowman \& Littlefield.

Becker, H., Namaan, Mor \&Gravano, L. (2011). Beyond Trending Topics: RealWorld Event Identification on Twitter (Tech Report).Association for the Advancement of Artificial Intelligence (www.aaai.org). $438-$ 441.https://pdfs.semanticscholar.org/2 573/060fb7b47e1a69933a28118fc9fd6 0c393ff.pdf.

Clark, K. A. (2004). Brandscendence: Three essential elements of enduring brands. Chicago, IL: Dearborn Trade Pub.

Chiaravalle, B. \& Schenck. B. F. (2014). Branding For Dummies. John Wiley \& Sons, Inc.

Dutta, S. and Pullig, C. (2011) Effectiveness of Corporate Responses to Brand Crises: The Role of Crisis Type and Response Strategies. Journal of Business Research, 64 , 1281-1287. http://dx.doi.org/10.1016/j.jbusres.201 1.01 .013

Eagle, L. and Kitchen, P.J. (2000).IMC, brand communications, and corporate cultures: Client/advertising agency co-ordination and cohesion. European Journal of Marketing, 34(5/6), 667-686.

Echevarria, R. M. (2017). A Content Analysis of NFL Team Online Branding. Elon Journal of Undergraduate Research in Communications (Vol. 8), 96-104.

Fearn-Banks, K. (2011). Crisis Communication: A Casebook Approach ( $4^{\text {th }}$ ed.). New York: Routledge.

Goi, C.,\&Goi, M.T. (2011). Review on Models and Reasons of Rebranding.International Conference on Social Science and Humanity, 5, 445-449.

Hallgren, K. (2018). The Branding of New Ukraine: A Media Production Study of the Encoding-Decoding of Europeanness during Eurovision Song Contest. Södertörn University Library: SöderScholar. 18-19. https://www.divaportal.org/smash/get/diva2:1215322/F ULLTEXT01.pdf

Hampf, A., \& Lindberg-Repo, K. (2011). Branding: The Past, Present, and Future: A Study of the Evolution and Future of Branding. Hanken School of Economics Working Papers, 1(1), 1-28.
Keller, K.L. (2003). Brand synthesis:The multidimensionality of brand knowledge. Journal of Consumer Research, 29(4), 595-600.

Kotler, P. and Armstrong,G. (2010). Principles of Marketing (13th ed.), NJ: Pearson.

Miletsky, J. I., \& Smith, G. L. (2009). Perspectives on branding. Boston, MA: Course technology.

Rao,V. R.,Agarwal,M.K., and Dahlhoff,D. (2004). How Is Manifest Branding Strategy Related to the Intangible Value of a Corporation? The Journal of Marketing, 68(4), 126-141.

Reichheld, Frederick, F, \& Schefter, P. (2000). 'E-Loyalty: your secret weapon on the web', Harvard Business Review, vol. 78, pp. 105-13.

Salvador, A. B.\& Ikeda, A.A. (2018). Brand crisis management: the use of information for prevention, identification and management.Review of Business Management, $20 \quad$ (1) 74-91. htps://doi.org/10.7819/rbgn.v20i1.358 3

Tevi, A. C. (2013). The Effect of Multiple Rebranding on Customer Loyalty in Nigerian Mobile Telephony. International Journal of Marketing Studies,5(2), 120130.

https://doi.org/10.5539/ijms.v5n2p12

Van Heerde, H., Helsen, K. and Dekimpe, G.M. (2007) The Impact of a Product-Harm Crisis on Marketing Effectiveness. Marketing Science, 26, 230-245. http://dx.doi.org/10.1287/mksc.1060.0 227

Wood, L. (2000). Brands and brand equity: definition and management. Management Decision, 38(9), 662- 669. doi:10.1108/00251740010379100.

Xie, Y. and Peng, S.Q. (2009) How to Repair Customer Trust after Negative Publicity: The Roles of Competence, Integrity, Benevolence, and Forgiveness. Psychology and Marketing, 26, 572-589. http://dx.doi.org/10.1002/mar.20289 